\title{
Brønsted acid-mediated cyclization-dehydrosulfonylation/ reduction sequences: An easy access to pyrazinoisoquinolines and pyridopyrazines
}

\author{
Ramana Sreenivasa Rao and Chinnasamy Ramaraj Ramanathan*
}

\author{
Full Research Paper \\ Address: \\ Department of Chemistry, Pondicherry University, Puducherry - 605 \\ 014, India \\ Email: \\ Chinnasamy Ramaraj Ramanathan* - crrnath.che@pondiuni.edu.in \\ * Corresponding author \\ Keywords: \\ Brønsted acid; piperazine-2,6-diones; praziquantel; \\ pyrazinoisoquinoline; pyridopyrazine
}

\author{
Beilstein J. Org. Chem. 2017, 13, 428-440. \\ doi:10.3762/bjoc. 13.46 \\ Received: 27 December 2016 \\ Accepted: 16 February 2017 \\ Published: 07 March 2017 \\ Associate Editor: T. P. Yoon
}

(C) 2017 Rao and Ramanathan; licensee Beilstein-Institut.

License and terms: see end of document.

\begin{abstract}
An efficient and alternative synthetic approach has been developed to prepare various $N$-(arylethyl)piperazine-2,6-diones from 4-benzenesulfonyliminodiacetic acid and primary amines using carbonyldiimidazole in the presence of a catalytic amount of DMAP at ambient temperature. Piperazine-2,6-diones are successfully transformed to pharmaceutically useful pyridopyrazines or pyrazinoisoquinolines and ene-diamides via an imide carbonyl group activation strategy using a Brønsted acid. Subsequent dehydrosulfonylation reactions of the ene-diamides, in a one pot manner, smoothly transformed them to substituted pyrazinones. A concise synthesis of praziquantel (1) has also been achieved through this method.
\end{abstract}

\section{Introduction}

Piperazine is an important structural core found in many biologically active natural products [1]. Piperazines are also useful intermediates in the synthesis of a variety of drug molecules having important biological activities such as anticancer [2,3], antifungal [4], amoebiasis, trypanosomiasis, bilharziasis [5,6], and schistosomiasis [7,8]. Some are cell adhesion inhibitors [9] brandykinin receptor antagonists $[10,11]$ and chymase inhibitors [12]. Quinoxaline derivatives are known to act as aldose reductase $\left(\mathrm{ALR}_{2}\right)$ inhibitors and are active towards chronic diabetic complications including neuropathy, nephropathy, cataracts and retinopathy $[13,14]$. On the other hand, piperazi- none condensed tetrahydroisoquinolines (THIQs) are widespread in nature with interesting biological activities [15]. They are also found to be building blocks for the synthesis of many alkaloids (Figure 1) [16].

To synthesize pyrazinoisoquinoline and its derivatives, various approaches such as the Ugi multicomponent reaction [17] amidoalkylation [18,19], $N$-acyliminium ion cyclization [20] and a radical cyclization [21] have been reported. To this end, recently, we have reported the activation of an imide carbonyl group with $\mathrm{TfOH}$, for the synthesis of tetrahydroisoquinoline 
<smiles>O=C(C1CCCCC1)N1CC(=O)N2CCc3ccccc3C2C1</smiles>

1

praziquantel $(\mathrm{PZQ})$<smiles>[R]NC(=O)C[C@H]1C(=O)NC=CN1S(=O)(=O)c1cccc([R])c1</smiles>

4

bradykinin receptor antagonist<smiles>CCC1CN2CCc3cc(OC)c(OC)cc3C2CN1CC1Cc2cc(OC)c(OC)cc2CN1</smiles>

2

azaemetine<smiles>CC(C)OC(=O)C(=O)[C@H](Cc1ccccc1)NC(=O)CN1C=C(c2ccccc2)N(C(=O)c2ccccc2)[C@H](C(C)C)C1=O</smiles>

5

chymase Inhibitor<smiles>CCC1CN2CCc3cc(OC)c(OC)cc3[C@H]2CN1CC1NCCc2c1[nH]c1ccccc21</smiles>

2-azadeoxytubulosine<smiles>[X]c1nc2ccccc2n(CC(=O)O)c1=O</smiles>

6

quinoxaline derivatives

Figure 1: Selected active pyrazinoisoquinolines, 2-oxopiperazines and aldose reductase inhibitors (ALR2).

(THIQ) and tetrahydro- $\beta$-carboline (THBC) skeletons and related alkaloids [22-26].

The present study, describes the synthesis of 4-benzenesulfonylpiperazine-2,6-dione derivatives by using the combination of carbonyldiimidazole/4-dimethylaminopyridine (CDI/ DMAP). Even though there are an adequate number of reports available in the literature for the synthesis of piperazine-2,6dione derivatives [27]. To the best of our knowledge, this is the first report describing the synthesis of 4-benzenesulfonylpiperazine-2,6-diones at ambient temperature. The advantage of this methodology is that the more reactive and acid labile groups can be installed to the piperazine-2,6-diones at N-4 position, which would then be utilized for synthetically useful transformations to yield the corresponding products.

Further, these 4-benzenesulfonylpiperazine-2,6-diones were subjected to an imide carbonyl group activation strategy, to develop a practical approach to synthesize pyrazinoisoquinoline and pyridopyrazines via Brønsted acid assisted 6-exo-trig cyclization of arylethylpiperazine-2,6-diones.

\section{Results and Discussion}

Piperazine-2,6-diones are usually synthesized through an Ugi [30] multicomponent approach. The condensation of primary amines with benzyliminodiacetic acid at high temperatures or
$\mathrm{CDI}$ /THF at reflux leads also to the formation of piperazine-2,6diones (Scheme 1). Using CDI/THF under reflux conditions, the piperazine-2,6-dione 7a from 4-benzenesulfonyliminodiacetic acid was obtained only in $50 \%$ yield along with the formation of benzenesulfonic acid (Table 1, entry 1). The formation of benzenesulfonic acid may be due to the labile nature of the benzenesulfonyl protecting group. Therefore, the reactions were performed at temperatures below $70{ }^{\circ} \mathrm{C}$ and a higher yield of piperazine-2,6-dione 7a was observed at $60{ }^{\circ} \mathrm{C}$ (Table 1, entry 2). Further lowering of the reaction temperature did not improve the yield of 7a (Table 1, entry 3). Hence, there is a need to develop a method for the preparation of piperazine-2,6-dione derivatives from $N$-benzenesulfonyliminodiacetic acid at room temperature. After careful reviewing of reagents for amide bond formation, the reagent CDI proved to be a very successful reagent for the preparation of imides, amides, esters and thioesters. Therefore, the reaction was carried out with $\mathrm{N}$-benzenesulfonyliminodiacetic acid, a primary amine and CDI ( 2 equiv) in THF, the corresponding piperazine-2,6-dione $7 \mathbf{a}$ was obtained in $21 \%$ yield at room temperature (Table 1, entry 4).

To facilitate the peptide bond formation DMAP has been used in conjuncture with coupling reagents such as DCC. We presumed that the use of DMAP along with CDI may facilitate the imide bond formation at room temperature. Hence, the reac- 


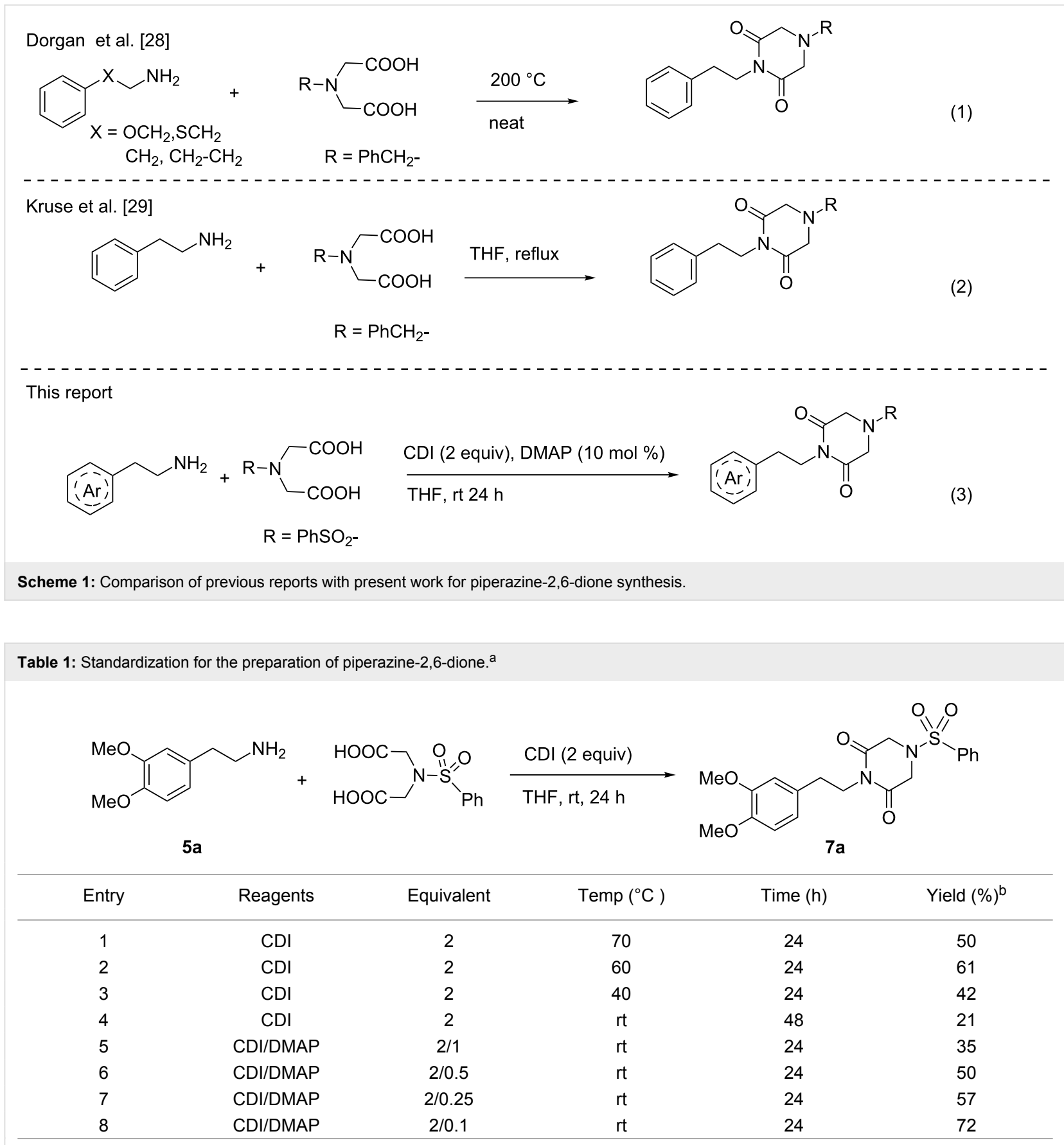

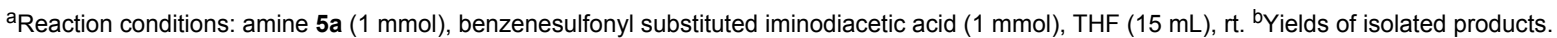

tion of 5 a with $N$-benzenesulfonyliminodiacetic acid was carried out using CDI in the presence of DMAP (Table 1, entries 5-8). Piperazine-2,6-dione 7a was obtained in 72\% yield at room temperature in the presence of $10 \mathrm{~mol} \%$ of DMAP. Similarly, this strategy has been extended to couple various arylethylamines with $N$-benzenesulfonyliminodiacetic acid at room temperature to furnish expected imides $\mathbf{7 a}-\mathbf{h}$ in good yields (Scheme 2).
The successful development of this methodology for the synthesis of 1-arylethylpiperazine-2,6-diones intrigued us to examine them in 6-exo-trig cyclization using $\mathrm{TfOH}$ followed by reduction with $\mathrm{NaBH}_{4} / \mathrm{MeOH}$ to accomplish the synthesis of tetrahydropyrazinoisoquinoline. Surprisingly, the reaction of $7 \mathbf{a}$ furnished a mixture of ene-diamide 9a and substituted pyrazinone 10a in 90:10 ratio. Generally, the syntheses of these types of units are very limited in the literature [31]. Under controlled 


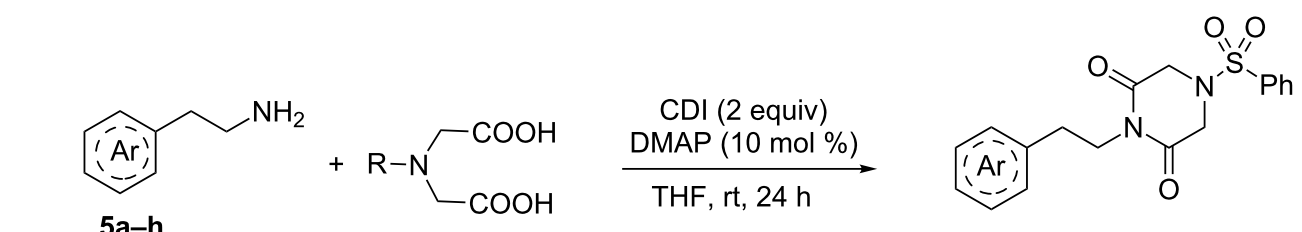

$5 a-h$

$\mathrm{Ar}=$ Aryl/Heteroaryl $\quad \mathrm{R}=\mathrm{PhSO}_{2}-$

7a-h, 68-78\%<smiles>COc1cc(CCN2C(=O)CN(S(=O)(=O)c3ccccc3)CC2=O)cc(OC)c1</smiles>

$7 a, 72 \%$<smiles>COc1cc(CCN2C(=O)CN(S(=O)(=O)c3ccccc3)CC2=O)cc(OC)c1OC</smiles>

7d, $68 \%$<smiles>O=C1CN(S(=O)(=O)c2ccccc2)CC(=O)N1CCc1cccs1</smiles>

$7 e, 75 \%$<smiles>COc1cccc(CCN2C(=O)CN(S(=O)(=O)c3ccccc3)CC2=O)c1</smiles>

$7 c, 70 \%$<smiles>O=C1CN(S(=O)(=O)c2ccccc2)CC(=O)N1CCc1cc2ccccc2s1</smiles>

7f, $72 \%$<smiles>O=C1CN(S(=O)(=O)c2ccccc2)CC(=O)N1CCc1c[nH]c2ccccc12</smiles>

$7 \mathrm{~g}, 78 \%$<smiles>O=C1CN(S(=O)(=O)c2ccccc2)CC(=O)N1CCc1ccccc1</smiles>

$7 \mathrm{~h}, 68 \%$

Scheme 2: Coupling of $N$-benzenesulfonyliminodiacetic acid with primary amines using CDI/DMAP.

experimental conditions, in the absence of $\mathrm{NaBH}_{4} / \mathrm{MeOH}$, the ene-diamide 9a was successfully generated in 90\% yield using 4 equivalents of $\mathrm{TfOH}$ in 30 minutes from $7 \mathbf{a}$.

While increasing the reaction time from 30 minutes to $2 \mathrm{~h}$, the formation of biologically active pyrazinone 10a has been realized as a major product along with ene-diamide 9a. A literature survey revealed that sulfonamides are known to undergo hydrolysis in the presence of a Brønsted acid [32]. Sulfonamides also participate in amide hydrolysis with external nucleophiles such as phosphide anions [33] or phenyldimethylsilyllithium [34]. The combinations of thiophenol/ $\mathrm{K}_{2} \mathrm{CO}_{3}$ [35] or $\mathrm{NaOH} / \mathrm{MeOH}$ [36] are also known to hydrolyse sulfonamides. These methods lead to the formation of the corresponding free amines. Such desulfonylation of sulfonamides has been less utilized to make an unsaturated bond, for example, imine. Hence, attention has been paid to find suitable conditions for the formation of pyrazinones directly from piperazine-2,6-diones via cyclization followed by dehydrosulfonylation (Scheme 3 ).

Following extensive optimization, it was realized that after cyclization, addition of $\mathrm{MeOH}$ followed by reflux proved to be suitable conditions to generate the substituted pyrazinones. The formation of substituted pyrazinones through dehydrosulfonylation (1,2-elimination) may be facilitated by 3 -factors, such as, (i) extended conjugation in pyrazinones, (ii) good leaving capacity of the benzenesulfonyl group and (iii) the presence of an acidic proton which is $\alpha$ to the amide carbonyl group. Hence, we believe that the selective elimination of the sulfonyl group in refluxing methanol would serve as a simple and novel alternate methodology to the reported oxidative strategy [37] for the syntheses of substituted pyrazinones. To demonstrate the gener- 


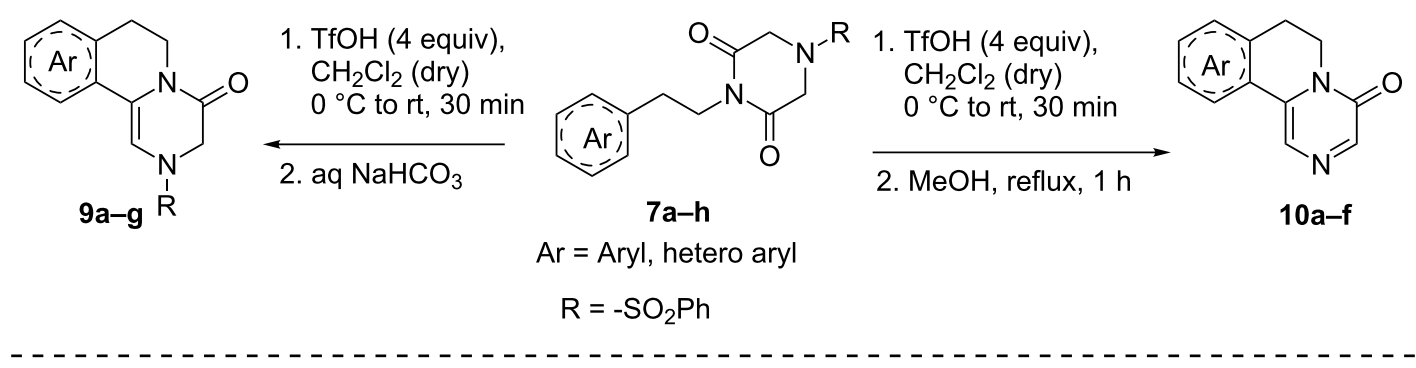<smiles>[R]N1C=C2c3cc(OC)c(OC)cc3CCN2C(=O)C1</smiles>

9a, $90 \%$<smiles>[R]N1C=C2c3c(cc(OC)c(OC)c3OC)CCN2C(=O)C1</smiles>

9d, $85 \%$<smiles>[R]N1C=C2c3c(cc(OC)cc3OC)CCN2C(=O)C1</smiles>

9b, $87 \%$<smiles>[R]N1C=C2c3ccc(OC)cc3CCN2C(=O)C1</smiles>

9c, $91 \%$<smiles>[R]N1C=C2c3ccsc3CCN2C(=O)C1</smiles>

9e, $85 \%$

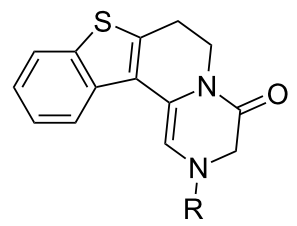

9f, $72 \%$<smiles>[R]N1C=C2c3[nH]c4ccccc4c3CCN2C(=O)C1</smiles>

gg, $86 \%$<smiles>COc1cc2c(cc1OC)-c1cncc(=O)n1CC2</smiles>

10a, $93 \%$<smiles>COc1cc2c(c(OC)c1OC)-c1cncc(=O)n1CC2</smiles>

10d, $80 \%$<smiles>COc1cc2c(c(OC)c1)-c1cncc(=O)n1CC2</smiles>

10b, $82 \%$<smiles>O=c1cncc2n1CCc1sccc1-2</smiles>

10e, $90 \%$<smiles>COc1ccc2c(c1)CCn1c-2cncc1=O</smiles>

10c, $85 \%$<smiles>O=c1cncc2n1CCc1sc3ccccc3c1-2</smiles>

10f, $76 \%$

Scheme 3: Formation of ene-diamides $9 \mathbf{a}-\mathbf{g}$ and pyrazinones $10 \mathbf{a}-\mathbf{f}$.

ality of this procedure various methoxy/methyl substituted phenethyl and heterocyclic ethylpiperazine-2,6-diones $7 \mathbf{a}-\mathbf{g}$ have been successfully converted to the substituted pyrazinones $\mathbf{1 0 a}-\mathbf{f}$ in excellent yields as shown in Scheme 3. To elucidate the mechanism involved in the formation of substituted pyrazi- nones, the aliquot obtained from the reaction of $7 \mathbf{c}$ with $\mathrm{TfOH}$ followed by reflux in $\mathrm{MeOH}$, was analyzed through ESI-HRMS technique. The appearance of peaks at $\mathrm{m} / \mathrm{z}=$ 143.0030 and $\mathrm{m} / \mathrm{z}=159.0773$ indicates the formation of benzenesulfinic acid and benzenesulfonic acid, respectively. 


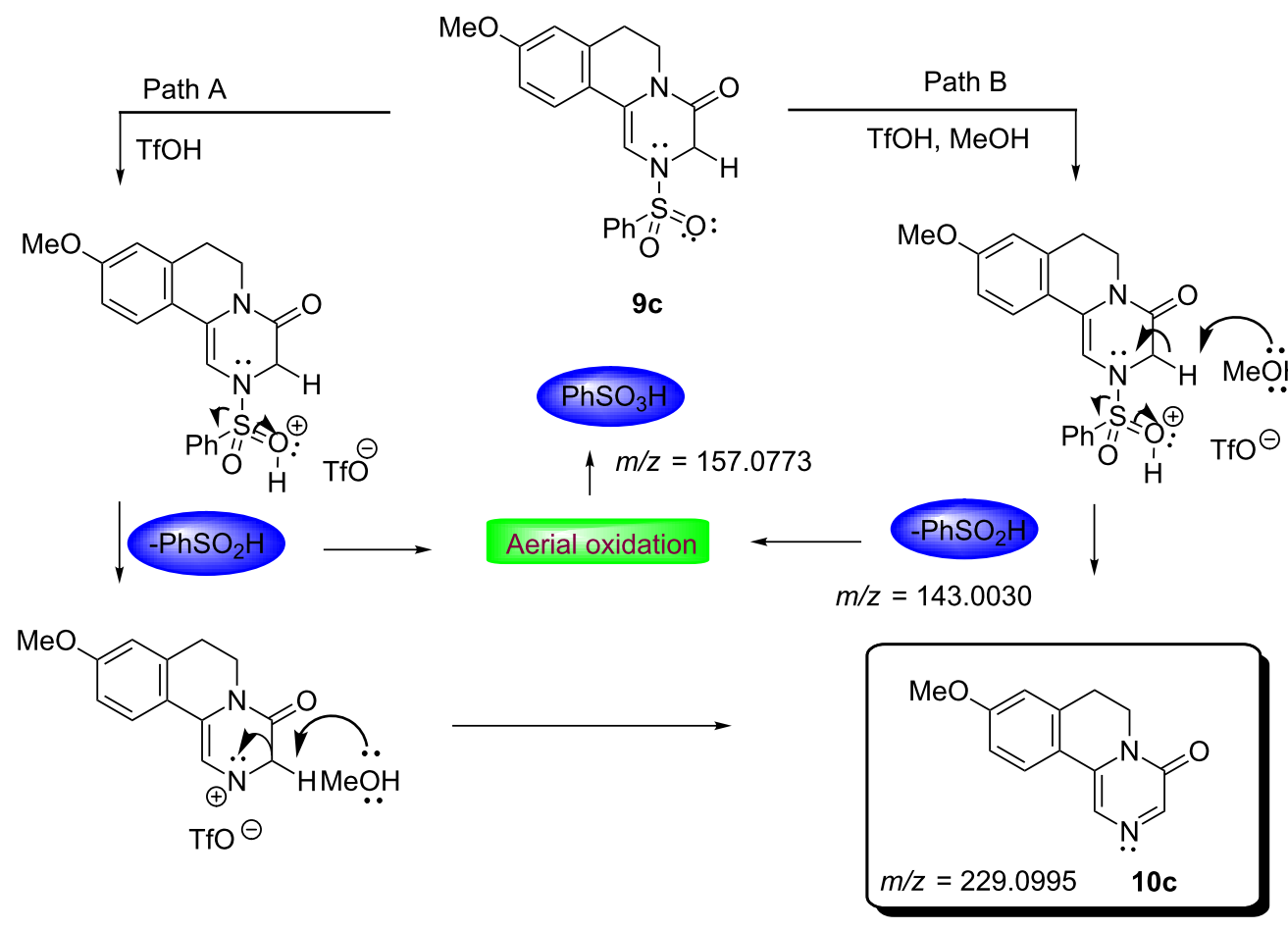

Scheme 4: Mechanism for the formation of substituted pyrazinones.

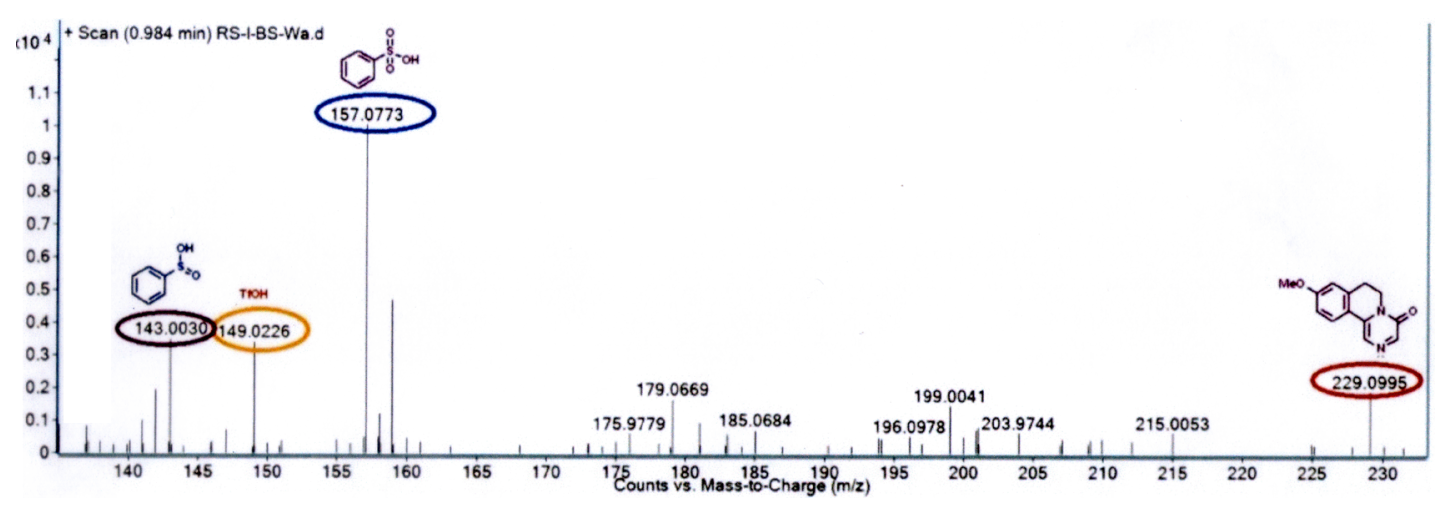

Figure 2: HRMS spectra of aliquot generated from cyclization reaction of 7c.

The formation of benzenesulfinic acid could be explained through a desulfonylization reaction via a 1,2-elimination process (Scheme 4 and Figure 2).

The structural evidence for cyclized compounds $9 \mathbf{b}$ and $\mathbf{1 0 a}$ was supported by single-crystal X-ray diffraction analysis (Figure 3 ) in addition to IR, NMR and HRMS data.

To show the synthetic utility of substituted pyrazinones, we introduce a phenyl group at the $\mathrm{C}-3$ position in pyrazinone de- rivative 10a. To begin with, the phenyl group was proposed to introduce at the 3-position in substituted pyrazinone via regioselective bromination followed by Suzuki coupling with phenylboronic acid. Accordingly, the bromination of $\mathbf{1 0 a}$ was successfully carried out to furnish regioisomers $\mathbf{1 2 a}$ and $\mathbf{1 2 b}$ in $82 \%$ yield upon treatment with bromodimethylsulfonium bromide (BDMS) [38] in dichloromethane at $0{ }^{\circ} \mathrm{C}$ to room temperature. The conventional Suzuki coupling of the regioisomers 12a and 12b with phenylboronic acid furnished the corresponding arylated products 13a and 13b in excellent yield (Scheme 5). 


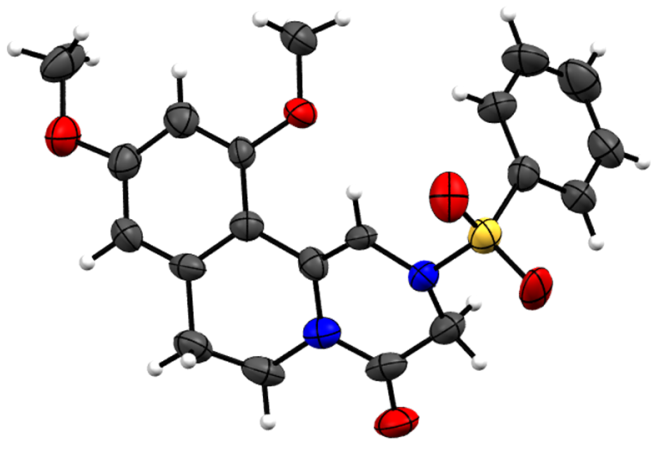

$9 b$

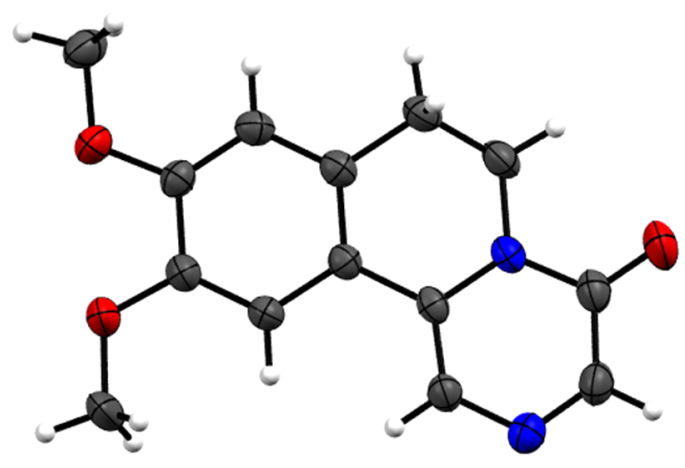

$10 a$

Figure 3: ORTEP diagrams of compound $9 \mathrm{~b}$ and $10 a$.<smiles>COc1cc2c(cc1OC)-c1cncc(=O)n1CC2</smiles>

$10 a$<smiles>COc1cc2c(cc1OC)-c1cnc(Br)c(=O)n1CC2</smiles>

$12 a$<smiles>COc1cc2c(cc1OC)-c1c(Br)ncc(=O)n1CC2</smiles>

$12 b$

$12 a: 12 b=79: 21$<smiles>COc1cc2c(cc1OC)-c1cnc(-c3ccccc3)c(=O)n1CC2</smiles>

$13 a$<smiles>COc1cc2c(cc1OC)-c1c(-c3ccccc3)ncc(=O)n1CC2</smiles>

13b

$13 a: 13 b=92: 8$

Scheme 5: Synthesis of 3-phenylpyrazinone.

To our dismay, the imide $\mathbf{7 h}$ did not participate in the cyclization reaction in the presence of $\mathrm{TfOH}$ at room temperature to generate a potential precursor for the synthesis of praziquantel. To realize the cyclization, the imide $\mathbf{7 h}$ was treated with $\mathrm{TfOH}$ under neat conditions at $70{ }^{\circ} \mathrm{C}$, quite unfortunately to witness the decomposition of imide $\mathbf{7 h}$. This may be due to the labile nature of the benzenesulfonyl group in $\mathbf{7 h}$. To avoid this decomposition problem, the amino group in iminodiacetic acid was protected as a $N$-benzyl group instead of a $N$-benzenesulfonyl group. Accordingly, the potassium salt of $N$-benzyliminodiacetic acid was synthesized following the reported procedure [39]. The $N$-protected $N$-phenethylpiperazine-2,6-dione $\mathbf{8 h}$ was formed, while treating the potassium salt of $N$-benzyliminodiacetic acid with phenethylamine in presence of CDI in THF under reflux conditions. Similarly, this strategy has been extended to couple arylethylamines with the potassium salt of
$\mathrm{N}$-benzyliminodiacetic acid in THF at reflux to furnish the expected imides $8 \mathbf{8}-\mathbf{c}, \mathbf{8 h}$, and $\mathbf{8 i}$ in good yields (Scheme 6).

The imide $\mathbf{8 h}$ was subjected to the cyclization reaction conditions using 6 equivalents of $\mathrm{TfOH}$ under neat conditions at $70{ }^{\circ} \mathrm{C}$ followed by reduction using $\mathrm{NaBH}_{4} / \mathrm{MeOH}$ at room temperature, which successfully furnished $N$-benzylpraziquantel $11 \mathrm{~h}$ in $75 \%$ yield. The electron rich phenethyl group containing imides 8a-c, electron rich heteroaryl ethyl imide 8i, smoothly delivered the cyclized products $11 \mathbf{a}-\mathbf{c}$ and $11 \mathbf{i}$ in excellent yields through the cyclization followed by the reduction sequence at room temperature (Scheme 7).

The synthesis of praziquantel from intermediate $\mathbf{1 1 h}$ was accomplished through $N$-debenzylation at $80{ }^{\circ} \mathrm{C}$ under 1 atmosphere of $\mathrm{H}_{2}$ in the presence of $\mathrm{Pd} / \mathrm{C}$ [40]. The present synthe- 


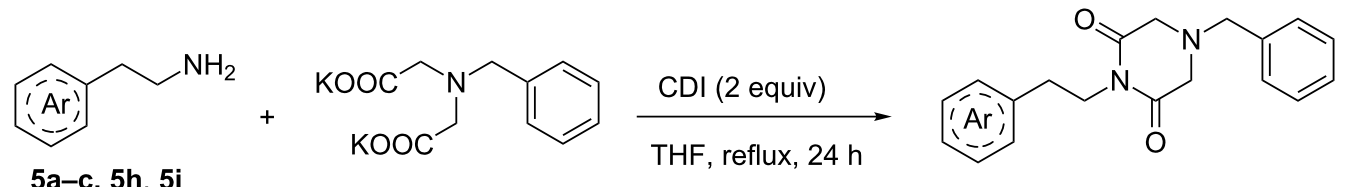

5a-c, 5h, 5i

$\mathrm{Ar}=\mathrm{Aryl} /$ Heteroaryl

8a-c, 8 h, $8 \mathbf{i}, 68-78 \%$<smiles>COc1cc(CCN2C(=O)CN(Cc3ccccc3)CC2=O)cc(OC)c1</smiles>

$8 a, 68 \%$

$8 b, 70 \%$

$8 c, 68 \%$<smiles>O=C1CN(Cc2ccccc2)CC(=O)N1CCc1ccccc1</smiles>

8 h, $70 \%$<smiles>CCn1ccc(CCN2C(=O)CN(Cc3ccccc3)CC2=O)c1</smiles>

$8 \mathbf{i}, 78 \%$

Scheme 6: Synthesis of 4-N-benzyl-1-N-(aryl/heteroarylethyl)piperazine-2,6-dione.

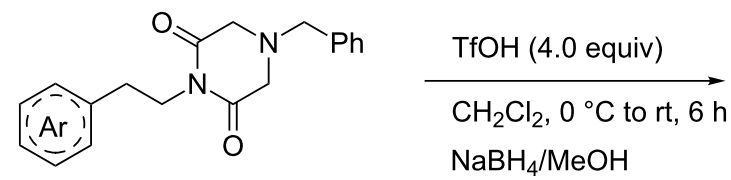

$8 a-c, 8 h, 8 i$

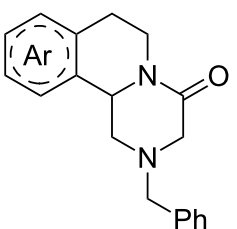

11a-c, 11h, 11i

(75-85\%)<smiles>COc1cc2c(cc1OC)C1CN(Cc3ccccc3)CC(=O)N1CC2</smiles>

11a, $85 \%$<smiles>COc1cc2c(c(OC)c1)C1CN(Cc3ccccc3)CC(=O)N1CC2</smiles>

11b, $82 \%$<smiles>COc1ccc2c(c1)CCN1C(=O)CN(Cc3ccccc3)CC21</smiles>

11c, $85 \%$<smiles>O=C1CN(Cc2ccccc2)CC2c3ccccc3CCN12</smiles>

11h, $75 \%$<smiles>CCn1ccc2c1CCN1C(=O)CN(Cc3ccccc3)CC21</smiles>

11i, $84 \%$ 
tic protocol involves the debenzylation reaction under milder conditions using $\mathrm{Pd}(\mathrm{OH})_{2}$ on charcoal $/ \mathrm{H}_{2}$ at room temperature followed by coupling the secondary amine with cyclohexanecarboxylic acid using CDI. Praziquantel (1) was obtained in $80 \%$ overall yield from $\mathbf{1 1 h}$ (Scheme 8 ).

\section{Conclusion}

In conclusion, an efficient and alternative synthetic approach has been developed to prepare various $N$-(arylethyl)piperazine2,6-diones. Brønsted acid assisted 6-exo-trig cyclization of piperazine-2,6-dione derivatives of aryl/heteroarylethylamines through carbonyl group activation to assemble the pyridoisoquinoline and pyrazinoisoquinoline derivatives have been demonstrated. The ene-diamides furnished the substituted pyrazinones through an acid-mediated dehydrosulfonylation in methanol. This strategy can be adopted to develop value added pyrazinone-based potential precursors useful to synthesize various drug targets. Further, the synthetic utility of pyrazinoisoquinoline was exemplified by the successful synthesis of fused tetrahydroisoquinoline drug molecule, praziquantel. Extending this strategy towards the stereoselective reduction of pyrazinones/ene-diamides is under investigation in our laboratory.

\section{Experimental}

\section{General procedure for the synthesis of 4-benzenesulfonylpiperazinone-2,6-diones 7a-h}

An oven-dried two-neck round-bottom flask that had a septum in the side arm was cooled to room temperature under a steady stream of nitrogen. The flask was charged with a stir bar, benzenesulfonyliminodiacetic acid ( $1 \mathrm{mmol})$, carbonyldiimidazole $(2 \mathrm{mmol})$ and $10 \mathrm{~mol} \%$ DMAP and dry THF $(25 \mathrm{~mL})$. Stirring was continued at room temperature to provide a clear solution. To this mixture was added aryl and heteroarylethylamine $(\mathbf{5 a}-\mathbf{h})(1 \mathrm{mmol})$ and the resulting solution was stirred at room temperature for $24 \mathrm{~h}$ (monitored by TLC). The solution was concentrated to dryness using a rotary evaporator under reduced pressure. The crude reaction product was purified by chromatography on a short silica gel column using ethyl acetate/hexane, (30:70) as eluent to afford $7 \mathbf{a}-\mathbf{h}$ in pure form.

\section{1-(3,4-Dimethoxyphenethyl)-4-(phenylsulfonyl)piper- azine-2,6-dione (7a)}

$300 \mathrm{mg}$, (72\% yield) colorless solid; mp $138-139{ }^{\circ} \mathrm{C}$; IR ( $\mathrm{KBr}$, $\mathrm{cm}^{-1}$ ): 3002, 2937, 2835, 1686, 1515, 1447, 1391, 1270, 1237, $1171,1114,1026,960,852,811,811,690,668,572,525 ;{ }^{1} \mathrm{H}$ NMR $\left(400 \mathrm{MHz}, \mathrm{CDCl}_{3}\right) \delta$ 7.79-7.78 (m, 2H), 7.66-7.62 (m, $1 \mathrm{H}), 7.59-7.55(\mathrm{~m}, 2 \mathrm{H}), 7.67(\mathrm{~d}, J=7.3 \mathrm{~Hz}, 1 \mathrm{H}), 6.69-6.66(\mathrm{~m}$, $2 \mathrm{H}), 4.11(\mathrm{~s}, 4 \mathrm{H}), 3.86(\mathrm{~s}, 3 \mathrm{H}), 3.84(\mathrm{~s}, 3 \mathrm{H}), 3.6-3.65(\mathrm{~m}, 2 \mathrm{H})$, 2.43-2.47 (m, 2H); ${ }^{13} \mathrm{C}$ NMR $\left(100 \mathrm{MHz}, \mathrm{CDCl}_{3}\right) \delta 166.4$, 149.0, 147.9, 135.6, 134.2, 130.0, 127.7, 120.9, 112.1, 111.4, 56.0, 48.9, 40.1, 33.4; HRMS-ESI $(\mathrm{m} / \mathrm{z})$ : $[\mathrm{M}+\mathrm{H}]$ calcd for $\mathrm{C}_{20} \mathrm{H}_{22} \mathrm{~N}_{2} \mathrm{O}_{6} \mathrm{~S}, 419.1277$; found, 419.1268 .

\section{General procedure for synthesis of 4-benzylpiperazinone-2,6-diones 8a-c, 8h, 8i}

An oven-dried two-neck round-bottom flask that had a septum in the side arm was cooled to room temperature under a steady stream of nitrogen. The flask was charged with a stir bar, the potassium salt of benzyliminodiacetic acid $(1 \mathrm{mmol})$ and carbonyldiimidazole ( $2 \mathrm{mmol}$ ) were added to dry THF $(25 \mathrm{~mL})$. The mixture was heated at refluxed for 10 min to obtain a clear solution. To this was added the aryl and heteroarylethylamines $(\mathbf{5 a}-\mathbf{c}, \mathbf{5 h}, \mathbf{5 i})(1 \mathrm{mmol})$ and the resulting solution was heated at reflux for $24 \mathrm{~h}$, then allowed to cool to room temperature. The solution was concentrated to dryness using a rotary evaporator under reduced pressure. The crude product was purified on a short silica gel column chromatography using ethyl acetate/ hexane (2:3) as eluent to afford $\mathbf{8 a}-\mathbf{c}, \mathbf{8 h}$, and $\mathbf{8 i}$ in pure form.

\section{4-Benzyl-1-(3,4-dimethoxyphenethyl)piperazine-2,6- dione (8a)}

$250 \mathrm{mg}$, (68\% yield) yellow liquid; IR ( $\left.\mathrm{KBr}, \mathrm{cm}^{-1}\right): 2950$, 2853, 1734, 1683, 1594, 1514, 1453, 1348, 1268, 1156, 1028, 806, 755, 704, 631; ${ }^{1} \mathrm{H}$ NMR (400 MHz, $\left.\mathrm{CDCl}_{3}\right) \delta 7.29-7.26$ $(\mathrm{m}, 1 \mathrm{H}), 7.24-7.21(\mathrm{~m}, 2 \mathrm{H}), 7.19-7.16(\mathrm{~m}, 2 \mathrm{H}), 6.70(\mathrm{~s}, 2 \mathrm{H})$,

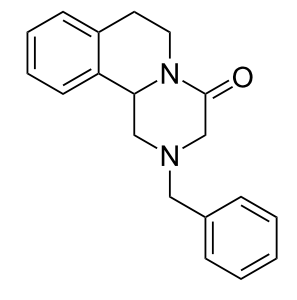

$11 \mathrm{a}$
1. $\mathrm{Pd}(\mathrm{OH})_{2}$ on charcoal, $\mathrm{H}_{2}, 12 \mathrm{~h}, \mathrm{rt}$

2. CDI, $12 \mathrm{~h}, \mathrm{rt}$ cyclohexyl-COOH 
$6.68(\mathrm{~s}, 1 \mathrm{H}), 3.94-3.86(\mathrm{~m}, 2 \mathrm{H}), 3.79(\mathrm{~s}, 3 \mathrm{H}), 3.76(\mathrm{~s}, 3 \mathrm{H}), 3.49$ (s, 2H), 3.29 (s, 4H), 2.72-2.68 (m, 2H); ${ }^{13} \mathrm{C} \mathrm{NMR} \mathrm{(100} \mathrm{MHz,}$ $\left.\mathrm{CDCl}_{3}\right) \delta 169.8,148.9,147.7,135.4,130.8,129.1,128.7$ $129.0,121.0,112.2,111.3,60.7,56.3,55.9,40.4,33.5$ HRMS-ESI $(m / z)$ : $[\mathrm{M}+\mathrm{H}]$ calcd for $\mathrm{C}_{21} \mathrm{H}_{24} \mathrm{~N}_{2} \mathrm{O}_{4}, 369.1814$; found, 369.1808 .

\section{General procedure for the cyclization of 4-benzenesulfonylpiperazinone-2,6-diones $7 a-g$}

Analogous as described in [26] an oven-dried two-neck roundbottom flask that had a septum in the side arm was cooled to room temperature under a steady stream of nitrogen. The flask was charged with a stir bar, imide $7 \mathbf{a}-\mathbf{g}(0.5 \mathrm{mmol})$, and dry dichloromethane $(15 \mathrm{~mL})$, and the resulting solution was cooled to $0{ }^{\circ} \mathrm{C}$ (by using ice). To this solution was added $\mathrm{TfOH}$ $(0.2 \mathrm{~mL}, 2 \mathrm{mmol})$ with stirring. After $30 \mathrm{~min}$, the reaction mixture was quenched with aqueous $\mathrm{NaHCO}_{3}$. The organic layer was separated, and the aqueous layer was extracted with dichloromethane $(2 \times 15 \mathrm{~mL})$. The combined organic extracts were washed with brine solution, dried over anhydrous $\mathrm{Na}_{2} \mathrm{SO}_{4}$ and filtered. The solution was concentrated to dryness by using a rotary evaporator. The dried crude product was purified by chromatography on a short silica gel chromatography column using ethyl acetate/hexane $(1: 1)$ as eluent to afford the $\mathbf{9 a}-\mathbf{g}$ in pure form.

\section{9,10-Dimethoxy-2-(phenylsulfonyl)-2,3,6,7- tetrahydro-4H-pyrazino[2,1-a]isoquinolin-4- one $(\mathbf{9 a})$}

$360 \mathrm{mg}$, (90\% yield) colorless liquid; IR $\left(\mathrm{KBr}, \mathrm{cm}^{-1}\right): 2927$, 2854, 1679, 1513, 1406, 1389, 1355, 1272, 1209, 1163, 1030, 992, 726, 576; ${ }^{1} \mathrm{H}$ NMR (400 MHz, $\left.\mathrm{CDCl}_{3}\right) \delta$ 7.82-7.79 (m, 2H), 7.59-7.55 (m, 1H), 7.51-7.47 (m, 2H), $6.92(\mathrm{~s}, 1 \mathrm{H}), 6.58$ $(\mathrm{d}, J=7.6 \mathrm{~Hz}, 2 \mathrm{H}), 4.18(\mathrm{~s}, 2 \mathrm{H}), 3.91(\mathrm{~s}, 3 \mathrm{H}), 3.86(\mathrm{~s}, 3 \mathrm{H})$, $3.48-3.45(\mathrm{~m}, 2 \mathrm{H}), 2.58-2.55(\mathrm{~m}, 2 \mathrm{H}) ;{ }^{13} \mathrm{C} \mathrm{NMR}(100 \mathrm{MHz}$, $\left.\mathrm{CDCl}_{3}\right) \delta 162.0,149.9,148.6,137.0,133.6,129.3,127.3$, 127.0, 119.9, 110.9, 106.4, 104.0, 56.4, 56.0, 48.3, 38.1, 28.0; HRMS-ESI $(\mathrm{m} / \mathrm{z})$ : $[\mathrm{M}+\mathrm{H}]$ calcd for $\mathrm{C}_{20} \mathrm{H}_{20} \mathrm{~N}_{2} \mathrm{O}_{5} \mathrm{~S}, 401.1171$; found, 401.1156 .

\section{General procedure for the synthesis of pyrazinones $10 a-f$}

Similar as described in [26] an oven-dried two-neck roundbottomed flask that had septum in the side arm was cooled to room temperature under a steady stream of nitrogen. The flask was charged with a stir bar, imide $7 \mathbf{a}-\mathbf{f}(0.5 \mathrm{mmol})$, and dry dichloromethane $(15 \mathrm{~mL})$, and the resulting solution was cooled to $0{ }^{\circ} \mathrm{C}$. To this solution was added TfOH $(0.2 \mathrm{~mL}, 2 \mathrm{mmol})$ with stirring. After the stipulated time, the contents were warmed to room temperature and methanol $(25 \mathrm{~mL})$ was added to the crude reaction mixture, the contents were refluxed for $1 \mathrm{~h}$ and then the solvent was evaporated to dryness under reduced pressure. The solid residue was dissolved in water and the aqueous layer was extracted with dichloromethane $(2 \times 15 \mathrm{~mL})$. The combined organic extracts were washed with brine solution, dried over anhydrous $\mathrm{Na}_{2} \mathrm{SO}_{4}$ and filtered. The solution was concentrated to dryness by using a rotary evaporator. The dried compound was purified through a short silica gel column chromatography using ethyl acetate/hexane mixture (1:1) as eluent to afford the $\mathbf{1 0 a}-\mathbf{f}$ in pure form.

\section{9,10-Dimethoxy-6,7-dihydro-4H-pyrazino[2,1-a]iso- quinolin-4-one (10a)}

$240 \mathrm{mg}$, (93\% yield) yellow solid; mp $132-133{ }^{\circ} \mathrm{C}$; IR (KBr, $\left.\mathrm{cm}^{-1}\right)$ : 2926, 2850, 1680, 1514, 1354, 1162, 1030, 993, 732; ${ }^{1} \mathrm{H}$ NMR (400 MHz, $\left.\mathrm{CDCl}_{3}\right) \delta 8.04(\mathrm{~s}, 1 \mathrm{H}), 7.74(\mathrm{~s}, 1 \mathrm{H}), 7.17(\mathrm{~s}$, $1 \mathrm{H}), 6.74(\mathrm{~s}, 1 \mathrm{H}), 4.23-4.17(\mathrm{~m}, 2 \mathrm{H}), 3.94(\mathrm{~s}, 3 \mathrm{H}), 3.93(\mathrm{~s}, 3 \mathrm{H})$, 3.04-2.85 (m, 2H); $\left.{ }^{13} \mathrm{C} \mathrm{NMR} \mathrm{(100} \mathrm{MHz,} \mathrm{CDCl}_{3}\right) \delta 155.8$, 151.7, 148.9, 145.3, 135.5, 129.0, 119.8, 118.7, 110.8, 107.7, 56.3, 56.2, 38.7, 27.0; HRMS-ESI $(\mathrm{m} / \mathrm{z})$ : $[\mathrm{M}+\mathrm{H}]$ calcd for $\mathrm{C}_{14} \mathrm{H}_{14} \mathrm{~N}_{2} \mathrm{O}_{3}, 259.1083$; found, 259.1073 .

\section{General procedure for the cyclization of 4-benzylpiperazine-2,6-diones $\mathbf{8 a - c}, \mathbf{8 h}, \mathbf{8} \mathbf{i}$}

Similar as described in [26] an oven-dried two-neck roundbottom flask that had a septum in the side arm was cooled to room temperature under a steady stream of nitrogen. The flask was charged with a stir bar, imide $\mathbf{8 a}-\mathbf{c}, \mathbf{8 h}, \mathbf{8 i}(0.5 \mathrm{mmol})$, and dry dichloromethane $(10 \mathrm{~mL})$, and the resulting solution was cooled to $0{ }^{\circ} \mathrm{C}$ (by using ice). To this solution was added $\mathrm{TfOH}$ $(0.2 \mathrm{~mL}, 2 \mathrm{mmol})$ with stirring. After $6 \mathrm{~h}$ the reaction mixture was diluted with methanol $(2.5 \mathrm{~mL})$ followed by portion wise addition of $\mathrm{NaBH}_{4}(2 \mathrm{mmol})$. The solution was stirred until the color disappeared (Additional $\mathrm{NaBH}_{4}$ and $\mathrm{MeOH}$ were used if the color persisted for a long time). The solution was evaporated to dryness under reduced pressure. The residue was dissolved in water and extracted with dichloromethane $(2 \times 20 \mathrm{~mL})$. The organic layer was dried over anhydrous $\mathrm{Na}_{2} \mathrm{SO}_{4}$ and filtered. The solvent was evaporated under vacuum, and the crude product was purified by silica gel column chromatography using ethyl acetate/hexane (1:1) as eluent to afford the $11 \mathbf{a}-\mathbf{c}, \mathbf{1 1} \mathbf{h}$, and $11 \mathbf{i}$ in pure form.

\section{2-Benzyl-1,2,3,6,7,11b-hexahydro-4H- pyrazino[2,1-a]isoquinolin-4-one (11h)}

$219 \mathrm{mg}$, (75\% yield) yellow liquid; IR $\left(\mathrm{KBr}, \mathrm{cm}^{-1}\right)$ : 2926, 2824, 1646, 1517, 1457, 1258, 1147, 1033, 744; ${ }^{1} \mathrm{H}$ NMR (400 $\left.\mathrm{MHz}, \mathrm{CDCl}_{3}\right) \delta 7.28-7.23(\mathrm{~m}, 4 \mathrm{H}), 7.24-7.16(\mathrm{~m}, 1 \mathrm{H})$, 7.11-7.08 (m, 2H), 7.07-7.04 (m, 1H), 6.94-6.92 (m, 1H), 4.78 $(\mathrm{dd}, J=12.0,8.0 \mathrm{~Hz}, 1 \mathrm{H}), 4.70-4.65(\mathrm{~m}, 1 \mathrm{H}), 3.55-3.51(\mathrm{~m}$, $2 \mathrm{H}), 3.50-3.41(\mathrm{~m}, 2 \mathrm{H}), 2.91-2.87(\mathrm{~m}, 2 \mathrm{H}), 2.85-2.77(\mathrm{~m}, 2 \mathrm{H})$, 
2.67-2.62 (m, 1H), 2.30-1.96 (m, 1H); ${ }^{13} \mathrm{C} \mathrm{NMR}(100 \mathrm{MHz}$, $\left.\mathrm{CDCl}_{3}\right) \delta 166.7,136.5,134.9,132.2,129.3,129.2,128.6,127.7$, 127.1, 126.6, 124.7, 61.6, 57.0, 55.7, 55.5, 39.0, 28.7, 20.9; HRMS-ESI $(m / z):[\mathrm{M}+\mathrm{H}]$ calcd for $\mathrm{C}_{19} \mathrm{H}_{20} \mathrm{~N}_{2} \mathrm{O}, 293.1654$; found, 293.1730.

\section{Procedure for the synthesis 9,10-dimethoxy- 3-phenyl-6,7-dihydro-4H-pyrazino[2,1-a]iso- quinolin-4-one (13)}

An oven-dried two-neck round-bottom flask that had a septum in the side arm was cooled to room temperature under a steady stream of nitrogen. The flask charged with a stir bar, 3,4dimethoxypyrazinone $\mathbf{1 0 a}(1.0 \mathrm{mmol})$ and $\mathrm{CH}_{2} \mathrm{Cl}_{2}(5 \mathrm{~mL})$ at $0-5{ }^{\circ} \mathrm{C}$, bromodimethylsulfonium bromide (BDMS) (1.0 mmol, $0.223 \mathrm{~g}$ ) was added and stirred at room temperature. After $24 \mathrm{~h}$, the reaction mixture was washed with water $(2 \times 10 \mathrm{~mL})$ and extracted with $\mathrm{CH}_{2} \mathrm{Cl}_{2}(2 \times 10 \mathrm{~mL})$. The organic layers were combined and dried over anhydrous $\mathrm{Na}_{2} \mathrm{SO}_{4}$. Solvents were removed by evaporation in a rotary evaporator. The crude reaction mixture was purified through silica gel column chromatography using ethyl acetate/hexane, 30:70 as eluent to afford 12a and $\mathbf{1 2 b}$ in the ratio 79:21.

The regioisomers of bromopyrazinone (12a and $\mathbf{1 2 b})$ (1.0 mmol), bis(triphenylphosphine)palladium(II) chloride $(10 \mathrm{~mol} \%, 7 \mathrm{mg})$ in dimethylformamide $(2 \mathrm{~mL})$ was added phenylboronic acid (122 $\mathrm{mg}$ ) and $2 \mathrm{M}$ aqueous sodium carbonate $(0.8 \mathrm{~mL})$ under a nitrogen atmosphere. The reaction mixture was heated to $90{ }^{\circ} \mathrm{C}$ and stirred for $2 \mathrm{~h}$. The reaction mixture was quenched with water and the mixture was extracted with ethyl acetate. The organic phase was separated, dried over anhydrous $\mathrm{Na}_{2} \mathrm{SO}_{4}$, filtered and concentrated. The crude reaction mixture was purified through a short silica gel column chromatography using ethyl acetate/hexane 10:90 as eluent and afforded 13a and 13b in the ratio of 92:8.

\section{3-Bromo-9,10-dimethoxy-6,7-dihydro-4H- pyrazino[2,1-a]isoquinolin-4-one (12a)}

$275 \mathrm{mg}$, (82\% yield) orange yellow liquid; IR $\left(\mathrm{KBr}, \mathrm{cm}^{-1}\right)$ : 2924, 2856, 1727, 1511, 1456, 1362, 1272, 845; ${ }^{1} \mathrm{H}$ NMR (400 $\left.\mathrm{MHz}, \mathrm{CDCl}_{3}\right) \delta 7.54(\mathrm{~s}, 1 \mathrm{H}), 7.13(\mathrm{~s}, 1 \mathrm{H}), 6.74(\mathrm{~d}, J=9.6 \mathrm{~Hz}$, $1 \mathrm{H}), 4.26(\mathrm{t}, J=6.4 \mathrm{~Hz}, 2 \mathrm{H}), 3.94(\mathrm{~s}, 6 \mathrm{H}), 2.96(\mathrm{t}, J=6.4 \mathrm{~Hz}$, $2 \mathrm{H}) ;{ }^{13} \mathrm{C} \mathrm{NMR}\left(100 \mathrm{MHz}, \mathrm{CDCl}_{3}\right) \delta 152.7,152.0,149.0,137.9$, 136.0, 128.8, 118.5, 118.3, 110.9, 107.6, 56.4, 56.3, 40.9, 27.2; HRMS-ESI $(\mathrm{m} / z):[\mathrm{M}+\mathrm{H}]$ calcd for $\mathrm{C}_{14} \mathrm{H}_{13} \mathrm{BrN}_{2} \mathrm{O}_{3}$, 337.0188; found, 337.0171 .

\section{9,10-Dimethoxy-3-phenyl-6,7-dihydro-4H- pyrazino[2,1-a]isoquinolin-4-one (13a)}

$290 \mathrm{mg}$, (87\% yield) yellow liquid ; IR $\left(\mathrm{KBr}, \mathrm{cm}^{-1}\right)$ : 2924 , 2856, 1728, 1595, 1512, 1458, 1216; ${ }^{1} \mathrm{H}$ NMR (400 MHz,
$\left.\mathrm{CDCl}_{3}\right) \delta 8.35-8.30(\mathrm{~m}, 2 \mathrm{H}), 7.89(\mathrm{~s}, 1 \mathrm{H}), 7.46-7.39(\mathrm{~m}, 3 \mathrm{H})$, $7.22(\mathrm{~s}, 1 \mathrm{H}), 6.76(\mathrm{~s}, 1 \mathrm{H}), 4.30(\mathrm{t}, J=6.4 \mathrm{~Hz}, 2 \mathrm{H}), 3.95(\mathrm{~s}, 3 \mathrm{H})$, $3.94(\mathrm{~s}, 3 \mathrm{H}), 2.98(\mathrm{t}, J=6.4 \mathrm{~Hz} 2 \mathrm{H}) ;{ }^{13} \mathrm{C} \mathrm{NMR}(100 \mathrm{MHz}$, $\left.\mathrm{CDCl}_{3}\right) \delta 154.9,151.5,149.1,148.9,136.6,134.6,129.5$, 128.8, 128.1, 119.5, 119.3, 110.8, 107.5, 56.4, 56.2, 39.2, 27.3; HRMS-ESI $(\mathrm{m} / \mathrm{z})$ : $[\mathrm{M}+\mathrm{H}]$ calcd for $\mathrm{C}_{20} \mathrm{H}_{18} \mathrm{~N}_{2} \mathrm{O}_{3}, 335.1396$; found, 335.1383 .

\section{Procedure for the synthesis of praziquantel [2-(cyclohexanecarbonyl)-1,2,3,6,7,11b- hexahydro-4H-pyrazino[2,1-a]isoquinolin-4- one]}

An oven-dried two-neck round-bottom flask that had a septum in the side arm was cooled to room temperature under a steady stream of nitrogen. The flask was charged with a stir bar, 2-benzyl-1,2,3,6,7,11b-hexahydro-4H-pyrazino[2,1-a]isoquinolin-4-one (292 $\mathrm{mg}, 1 \mathrm{mmol})$, palladium hydroxide on charcoal $(30 \mathrm{mg})$ and ethyl acetate $(15 \mathrm{~mL})$. The reaction flask was degassed and filled with hydrogen gas twice through a rubber bladder and the contents were stirred under hydrogen atmosphere. After $24 \mathrm{~h}$, the reaction mixture was filtered through a small bed of celite and washed with ethyl acetate $(2 \times 10 \mathrm{~mL})$. The solvents were removed by evaporation using a rotary evaporator. The crude product was used in the next step without further purification

An oven-dried two-neck round-bottom flask that had a septum in the side arm was cooled to room temperature under a steady stream of nitrogen. The flask was charged with a stir bar, cyclohexanecarboxylic acid $(0.14 \mathrm{~mL}, 1.1 \mathrm{mmol})$ and carbonyldiimidazole (194 mg, $1.2 \mathrm{mmol})$ and dry THF (10 mL). The contents were stirred to obtain a clear solution. To this solution was added dropwise a solution of 1,2,3,6,7,11b-hexahydro- $4 H$ pyrazino[2,1- $a$ ] isoquinolin-4-one $(200 \mathrm{mg}, 2.32 \mathrm{mmol})$ in dry THF and the resulting solution was stirred at room temperature for $24 \mathrm{~h}$. The solution was concentrated to dryness using a rotary evaporator. The crude reaction mixture was purified by a short silica gel column chromatography using ethyl acetate/ hexane (10:90) as eluent to furnished praziquantel (1) in $249 \mathrm{mg},\left(80 \%\right.$ yield) as a white solid; mp $129-131^{\circ} \mathrm{C}$; IR (KBr, $\left.\mathrm{cm}^{-1}\right): 2928,2856,1660,1452,1211,1039,755,656$; ${ }^{1} \mathrm{H}$ NMR (400 MHz, $\left.\mathrm{CDCl}_{3}\right) \delta 7.21-7.13(\mathrm{~m}, 4 \mathrm{H}), 5.08$ (dd, $J=$ $13.2,2.4 \mathrm{~Hz}, 1 \mathrm{H}), 4.79-4.72(\mathrm{~m}, 2 \mathrm{H}), 4.39$ (d, $J=17.2 \mathrm{~Hz}, 1 \mathrm{H})$, $4.0(\mathrm{~d}, J=13.2 \mathrm{~Hz}, 1 \mathrm{H}), 2.91-2.69(\mathrm{~m}, 4 \mathrm{H}), 2.40(\mathrm{t}, J=11.6$ $\mathrm{Hz}, 1 \mathrm{H}), 1.73-1.65(\mathrm{~m}, 5 \mathrm{H}), 1.53-1.43(\mathrm{~m}, 2 \mathrm{H}), 1.23-1.17(\mathrm{~m}$, $3 \mathrm{H}) ;{ }^{13} \mathrm{C} \mathrm{NMR}\left(100 \mathrm{MHz}, \mathrm{CDCl}_{3}\right) \delta 174.9,164.6,134.6,132.6$, 129.2, 127.4, 126.9, 125.4, 54.9, 48.9, 45.1, 42.8, 40.7, 39.1, 29.1, 28.9, 28.8, 28.6, 25.7, 25.6, 25.3, 20.8; HRMS-ESI $(\mathrm{m} / \mathrm{z}):[\mathrm{M}+\mathrm{H}]$ calcd for $\mathrm{C}_{19} \mathrm{H}_{24} \mathrm{~N}_{2} \mathrm{O}_{2}, 313.1916$; found, 313.1905 . 


\section{Supporting Information}

\section{Supporting Information File 1}

${ }^{1} \mathrm{H}$ and ${ }^{13} \mathrm{C}$ NMR spectra of synthesized compounds.

[http://www.beilstein-journals.org/bjoc/content/

supplementary/1860-5397-13-46-S1.pdf]

\section{Acknowledgements}

We thank DST and CSIR, New Delhi for financial support. RSR thank UGC, New Delhi for SRF. We gratefully acknowledge the Department of Chemistry, Pondicherry University for HRMS data (DST-FIST Sponsored) and IR data; CIF, Pondicherry University for NMR data. We acknowledge IPLS programme, Pondicherry University.

\section{References}

1. Rathi, A. K.; Syed, R.; Shin, H.-S.; Patel, R. V. Expert Opin. Ther. Pat. 2016, 26, 777-797. doi:10.1080/13543776.2016.1189902

2. Chetan, B.; Bunha, M.; Jagrat, M.; Sinha, B. N.; Saiko, P.; Graser, G.; Szekeres, T.; Raman, G.; Rajendran, P.; Moorthy, D.; Basu, A.; Jayaprakash, V. Bioorg. Med. Chem. Lett. 2010, 20, 3906-3910. doi:10.1016/j.bmcl.2010.05.020

3. Adamczyk-Woźniak, A.; Czerwińska, K.; Madura, I. D.; Matuszewska, A.; Sporzyński, A.; Żubrowska-Zembrzuska, A. New J. Chem. 2015, 39, 4308-4315. doi:10.1039/C5NJ00084J

4. Tang, H.; Zheng, C.; Lv, J.; Wu, J.; Li, Y.; Yang, H.; Fu, B.; Li, C.; Zhou, Y.; Zhu, J. Bioorg. Med. Chem. Lett. 2010, 20, 979-982. doi:10.1016/j.bmcl.2009.12.050

5. Samuelson, J.; Ayala, P.; Orozco, E.; Wirth, D. Mol. Biochem. Parasitol. 1990, 38, 281-290. doi:10.1016/0166-6851(90)90031-G

6. Flickinger, C. J. Exp. Cell Res. 1972, 74, 541-546. doi:10.1016/0014-4827(72)90414-4

7. Steinmann, P.; Keiser, J.; Bos, R.; Tanner, M.; Utzinger, J. Lancet Infect. Dis. 2006, 6, 411-425. doi:10.1016/S1473-3099(06)70521-7

8. Caffrey, C. R. Curr. Opin. Chem. Biol. 2007, 11, 433-439. doi:10.1016/j.cbpa.2007.05.031

9. Lewis, I.; Rohde, B.; Mengus, M.; Weetall, M.; Maida, S.; Hugo, R.; Lake, P. Mol. Diversity 2000, 5, 61-73. doi:10.1023/A:1013990624215

10. Askew, B. C., Jr.; Aya, T.; Biswas, K.; Cai, G.; Chen, J. J.; Han, N.; Liu, Q.; Nguyen, T.; Nishimura, N.; Nomak, R.; Peterkin, T.; Qian, W.; Yang, K.; Yuan, C. C.; Zhu, J.; D'amico, D. C.; Nguyen, T.; Qian, W. 1,2,3,4-Tetrahydropyrazin-2-yl acetamides and their use as bradykinin antagonists for the treatment of inflammation related disorders. WO Patent WO019975, Feb 23, 2006.

11. Aya, T.; Cai, G.; Chen, J. J.; D'amico, D. C.; Nguyen, T.; Qian, W. Triazoles and their use as bradykinin b1 receptor antagonists. WO Patent WO044355, April 27, 2006.

12. Matsumoto, E. Novel thiazine or pyrazine derivatives. WO Patent WO0107419, Feb 1, 2001

13. Kao, Y.-L.; Donaghue, K.; Chan, A.; Knight, J.; Silink, M. Diabetes 1999, 48, 1338-1340. doi:10.2337/diabetes.48.6.1338

14. Alexiou, P.; Pegklidou, K.; Chatzopoulou, M.; Nicolaou, I.; Demopoulos, V. J. Curr. Med. Chem. 2009, 16, 734-752. doi:10.2174/092986709787458362
15. Caldwell, J. J.; Veillard, N.; Collins, I. Tetrahedron 2012, 68, 9713-9728. doi:10.1016/j.tet.2012.09.039

16. Kölzer, M.; Weitzel, K.; Göringer, H. U.; Thines, E.; Opatz, T. ChemMedChem 2010, 5, 1456-1464. doi:10.1002/cmdc.201000230

17. Cao, H.; Liu, H.; Dömling, A. Chem. - Eur. J. 2010, 16, 12296-12298. doi:10.1002/chem.201002046

18. Kim, C. S.; Min, D. Y. Arch. Pharmacal Res. 1998, 21, 744-748. doi:10.1007/BF02976769

19. Guglielmo, S.; Cortese, D.; Vottero, F.; Rolando, B.; Kommer, V. P.; Williams, D. L.; Fruttero, R.; Gasco, A. Eur. J. Med. Chem. 2014, 84, 135-145. doi:10.1016/j.ejmech.2014.07.007

20. Kim, J. H.; Lee, Y. S.; Park, H.; Kim, C. S. Tetrahedron 1998, 54, 7395-7400. doi:10.1016/S0040-4020(98)00401-3

21. Todd, M. H.; Ndubaku, C.; Bartlett, P. A. J. Org. Chem. 2002, 67, 3985-3988. doi:10.1021/jo010990m

22. Selvakumar, J.; Makriyannis, A.; Ramanathan, C. R. Org. Biomol. Chem. 2010, 2, 4056-4058. doi:10.1039/c0ob00269k

23. Selvakumar, J.; Ramanathan, C. R. Org. Biomol. Chem. 2011, 9 , 7643-7646. doi:10.1039/c1ob06349a

24. Mangalaraj, S.; Selvakumar, J.; Ramanathan, C. R. J. Chem. Sci. 2015, 127, 811-819. doi:10.1007/s12039-015-0836-8

25. Mangalaraj, S.; Ramanathan, C. R. RSC Adv. 2012, 2, 12665-12669. doi:10.1039/c2ra21734a

26. Selvakumar, J.; Rao, R. S.; Srinivasapriyan, V.; Marutheeswaran, S.; Ramanathan, C. R. Eur. J. Org. Chem. 2015, 2175-2188. doi:10.1002/ejoc.201403617

27. Henry, D. W. J. Heterocycl. Chem. 1966, 3, 503-511. doi:10.1002/jhet.5570030423

28. Brewer, M. D.; Burgess, M. N.; Dorgan, R. J. J.; Elliott, R. L.; Mamalis, P.; Manger, B. R.; Webster, R. A. B. J. Med. Chem. 1989, 32, 2058-2062. doi:10.1021/jm00129a007

29. Kruse, C. G.; Troost, J. J.; Cohen-Fernandes, P.; van der Linden, H.; van Loon, J. D. Recl. Trav. Chim. Pays-Bas 1988, 107, 303-309. doi:10.1002/recl.19881070402

30. Ugi, I.; Demharter, A.; Hörl, W.; Schmid, T. Tetrahedron 1996, 52, 11657-11664. doi:10.1016/0040-4020(96)00647-3

31. Lee, S.-C.; Park, S. B. J. Comb. Chem. 2007, 9, 828-835. doi: $10.1021 /$ cc0700492

32. Snyder, H. R.; Heckert, R. E. J. Am. Chem. Soc. 1952, 74, 2006-2009 doi:10.1021/ja01128a041

33. Yoshida, S.; Igawa, K.; Tomooka, K. J. Am. Chem. Soc. 2012, 134, 19358-19361. doi:10.1021/ja309642r

34. Fleming, I.; Frackenpohl, J.; Ila, H. J. Chem. Soc., Perkin Trans. 1 1998, 1229-1236. doi:10.1039/a709116h

35. Dar'in, D.; Bakulina, O.; Chizhova, M.; Krasavin, M. Org. Lett. 2015, 17, 3930-3933. doi:10.1021/acs.orglett.5b02014

36. Yadav, A. K.; Yadav, S. K. S.; Siddiqui, I.; Peruncheralathan, S.; Ila, H.; Junjappa, H. Synlett 2008, 2674-2680. doi:10.1055/s-0028-1083529

37. Kiec'-Kononowicz, K. Arch. Pharm. 1989, 322, 795-799. doi:10.1002/ardp.19893221104

38. Khan, A. T.; Ali, M. A.; Goswami, P.; Choudhury, L. H. J. Org. Chem. 2006, 71, 8961-8963. doi:10.1021/jo061501r

39. Merz, A.; Schropp, R.; Dötterl, E. Synthesis 1995, 795-800. doi:10.1055/s-1995-3993

40. Yuste, F.; Pallás, Y.; Barrios, H.; Ortíz, B.; Sánchez-Obregón, R. J. Heterocycl. Chem. 1986, 23, 189-190. doi:10.1002/jhet.5570230139 


\section{License and Terms}

This is an Open Access article under the terms of the Creative Commons Attribution License

(http://creativecommons.org/licenses/by/4.0), which permits unrestricted use, distribution, and reproduction in any medium, provided the original work is properly cited.

The license is subject to the Beilstein Journal of Organic Chemistry terms and conditions:

(http://www.beilstein-journals.org/bjoc)

The definitive version of this article is the electronic one which can be found at:

doi:10.3762/bjoc. 13.46 